Original Research

\title{
Sorption of Thallium on Walnut Shells and its Enhancement by the Lignosulfonate-Stabilized Gold Colloid
}

\author{
Bożena Karbowska, Emilia Konowal*, Włodzimierz Zembrzuski, \\ Grzegorz Milczarek
}

Institute of Chemistry and Technical Electrochemistry, Poznan University of Technology, Poznan, Poland

Received: 7 December 2017

Accepted: 4 March 2018

\begin{abstract}
The adsorption behavior of walnut shells in the presence of colloidal gold for thallium(I) ions from aqueous solution was investigated. The thallium content in the samples before and after contact with walnut shells was determined by differential pulse anodic stripping voltammetry. The adsorption capacity was studied in relation to the function of equilibrium time, the amount of adsorbent, the concentration of thallium, and $\mathrm{pH}$. For the sake of comparison, the sorptive properties of walnut shells were compared to soapnut powder.

The obtained results clearly indicate that both walnut shells and soap nuts are effective sorbents for thallium(I) ions (removal efficiency over 90\%). The best results of sorption were achieved at $\mathrm{pH}=7.5$ after contact time of $30 \mathrm{~min}$. The addition of colloidal gold stabilised by lignosulfonate as the co-adsorber enhances the sorption ability of walnut shells to over $99 \%$.
\end{abstract}

Keywords: bioadsorption, differential pulse voltammetry, gold nanoparticles, thallium removal, walnut shells

\section{Introduction}

Metals play an important role as trace elements in living organisms. However, many metals cause toxic effects [1]. Thallium belongs to a group of highly toxic elements. In living beings, thallium mimics potassium, which favors its accumulation. The toxicity of thalliumbased compounds is mainly caused by the similarity between thallium (I) ions and potassium ions [2, 3],

*e-mail: emilia.konowal@put.poznan.pl which results in disorder of potassium-associated metabolic processes due to thallium interference [4]. In particular, it accumulates in the internal organs: the liver, kidneys, and muscles, as well as in bones and hair. In addition, it will deteriorate enzyme activity and cause inactivation of sulfhydryl groups $(-\mathrm{SH})$, leading to disturbances in the operation of mitochondria [5]. Basically, there are three methods of thallium intoxication: (i) inhalation, (ii) ingestion, and (iii) contact with the skin. Ingested thallium can enter the body through contaminated water or food, like vegetables, fruits, or meat. It should be noted that the 
amount of thallium in air - as established by the U.S. Occupational Safety and Health Administration (OSHA) - cannot exceed the limit of $0.1 \mathrm{mg} \cdot \mathrm{m}^{-3}$.

The rapid development of technology and industry causes the emission of thallium into the environment in the amount of 5,000 tons per year [6]. The content of thallium in river waters in Poland ranges from 5 to $17 \mathrm{ng} \mathrm{L}^{-1}[7,8]$. The water samples collected from the Silesian-Cracow region were characterized by a higher thallium content that ranged from 0.16 to $3.24 \mu \mathrm{g} \mathrm{L}^{-1}$ [9]. Seawater usually contains $10-15 \mathrm{ng} \mathrm{L}^{-1}$ of thallium. Although the content of thallium in underground water samples amounts to $20-24 \mu \mathrm{g} \mathrm{L}^{-1}$, in deep groundwater samples it ranges from 13 to $1100 \mu \mathrm{g} \mathrm{L}^{-1}[7,8]$.

Thallium occurs in small quantities in sulfide ores $(\mathrm{Fe}, \mathrm{Zn}, \mathrm{Cu}, \mathrm{Pb})$ and in the ore selenite $(\mathrm{Cu}, \mathrm{Ag})$. Therefore, the extensive mining of sulfide ores, the flotation and smelting process (especially near zinc and lead smelters) are the major sources of anthropogenic thallium pollution [10]. Areas with high levels of thallium are found all over the world, including in the Czech Republic [11], Poland [12], Spain [13], and China $[14,15]$. The main source of thallium compounds in air is the energy industry (especially the burning of fossil fuels).

Various methods have been used to remove metal ions from aqueous solutions, including reduction, ion exchange, electrodialysis, electrochemical precipitation, evaporation, extraction, osmosis, chemical precipitation, coagulation, ultrafiltration, and adsorption [16, 17]. Many of these processes are characterized by high costs and problems with the disposal of the wastes thereby obtained. One of the most important factors affecting the capacity of adsorbent in wastewater treatment is $\mathrm{pH}$. The efficiency of adsorption depends on the solution $\mathrm{pH}$, since variation in $\mathrm{pH}$ leads to the variation in the degree of ionisation of the adsorptive molecule and the surface properties of the adsorbent [18, 19].

In recent years literature has included issues concerning the biosorption of thallium through the use of, for example, green algae as biosorbents [20, 21], fungal isolates [22], Turbificidae, Chironomid larvae, and Loach [23]. Biosorption is a rapid and reversible process [24]. It can be conducted on living or inanimate material. It does not require metabolic processes. Certain impurities are adsorbed on the surface in contrast to bioaccumulation, in which a partial adsorption of contaminants into the cells occurs. The binding of ions can involve physical adsorption, ion exchange, chemical adsorption, complexation, chelating, and microprecipitation.

The past decade has brought an increased interest in noble metal nanostructures, particularly gold. Due to their attractive and unique structural, electronic, optical, thermal, and catalytic properties, gold nanostructures are of interest to many fields of science, including physics, chemistry, biology, medicine, materials science, and various interdisciplinary fields (e.g., for the production of biosensors, chemisensors, and in catalysis or electrocatalysis) $[25,26]$.

Noble metal nanostructures interact with heavy metals. As a result, aggregates are formed. In the case of gold colloid, in the presence of heavy metal ions, the colour of the solution changes from red (characteristic of the gold nanostructures) to blue or colourless. This phenomenon has been utilized in the colorimetric determination of heavy metal ions in water and wastewater [27-31].

In this work, a study was carried out to verify the suitability of walnut shell and soap nuts as cheap and readily available biosorbents of thallium. $\mathrm{pH}$ should be considered as the important parameter that affects thallium adsorption from an aqueous solution. Therefore, in this study, experimental work was performed to characterize the $\mathrm{pH}$-dependent adsorption behaviors of thallium in aqueous-solution on walnut shells. This experiment includes equilibrium and kinetic studies as well as adsorption in terms of the initial solution $\mathrm{pH}$. Additionally, the effect of gold nanoparticles stabilized with lignosulfonates on adsorption efficiency was studied.

\section{Material and Methods}

\section{Apparatus and Reagents}

Thallium concentration was determined using differential pulse voltammetry (DPASV) using a mercury film electrode and a flow-through electrochemical cell that allows exchanging of the base electrolyte. This method allows for detection of concentrations of thallium as low as $0.25 \mathrm{pM}$, which makes this method very accurate [32]. A peristaltic pump (Ismatec) operating at a flow rate of $2 \mathrm{~cm}^{3} / \mathrm{min}$ and an electrochemical analyzer $\mu$-AUTOLAB ECOCHEMIE (the Netherlands) were used for this purpose.

A mercury film electrode (MFE) based on epoxy resin-impregnated graphite was used as the working electrode. A saturated calomel electrode (SCE) was the reference electrode and a platinum wire served as the auxiliary electrode. The mercury film was deposited over a period of $10 \mathrm{~min}$ from a solution consisting of $0.05 \mathrm{mM}$ mercury(II) nitrate and $0.1 \mathrm{M}$ potassium nitrate at a constant potential of $-1 \mathrm{~V}$. One mercury film was sufficient for a whole day of measurements. The scheme of the working system is presented in Fig. 1a), and scanning electron micrographs (SEM)of the working electrode surface are presented in Fig. 1e).

The accuracy of the analysis was verified using a certified reference material GBW 07401 (Chinese soil) containing $1.0 \pm 0.2 \mathrm{ppm}$ of thallium. Nine independent trials were conducted for the reference material in order to determine the metal content. The average content of $\mathrm{Tl}$ was at $0.90 \pm 0.14 \mu \mathrm{g} \mathrm{g}^{-1}$ (with a minimum 0.76 of and a maximum of $1.1 \mu \mathrm{g} \mathrm{g}^{-1}$ ). The recovery of $\mathrm{Tl}$ was at $90 \%$. 
Ammonia solution (25\%), nitric acid (65\%), and EDTA (all provided by Fluka) were used. All solutions were prepared in water by reverse osmosis in a WatekDemiwa 5 Rosa system (Czech Republic).

a)

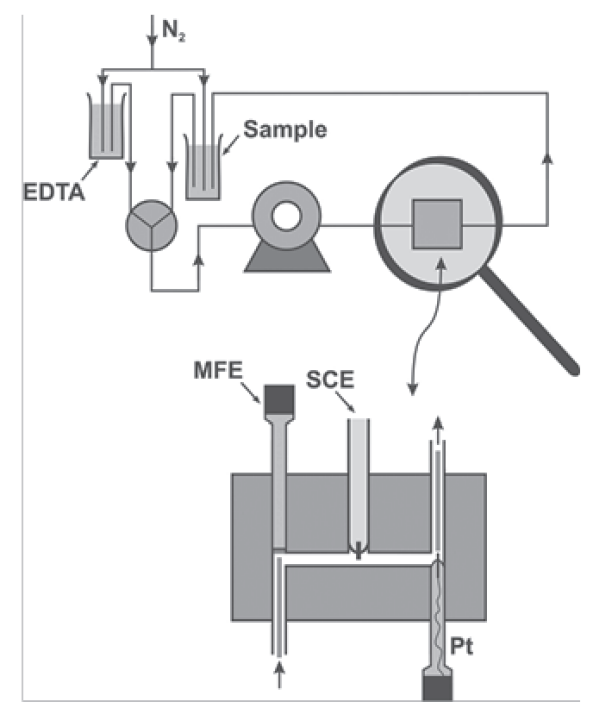

c)

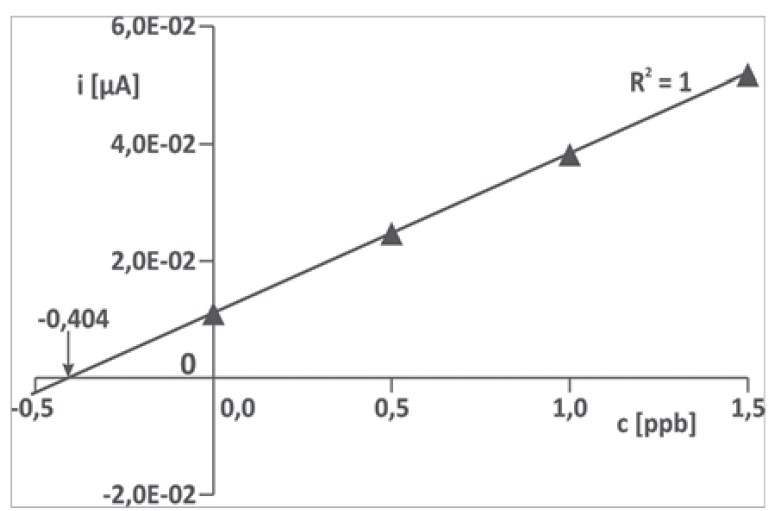

\section{Preparing the Biosorbents}

The raw material for this study was walnuts grown in ecological conditions (organic farm) and commercially available soap nuts (Ecoboom).

b)

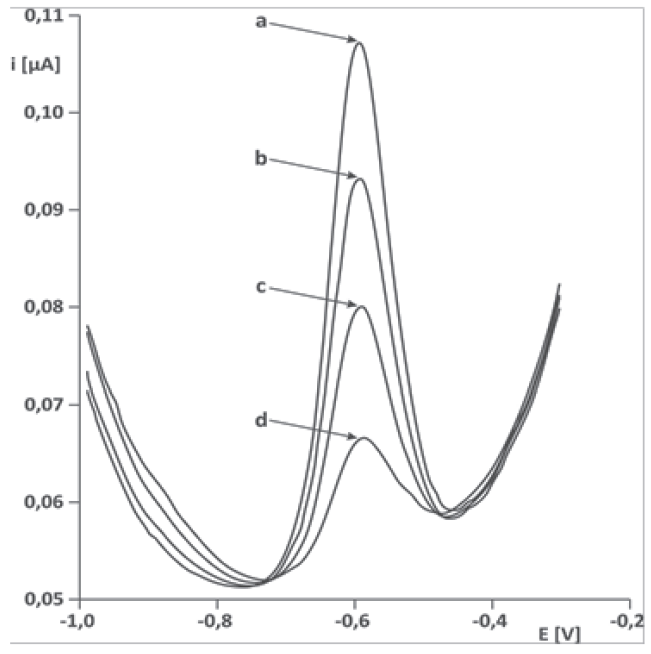

d)

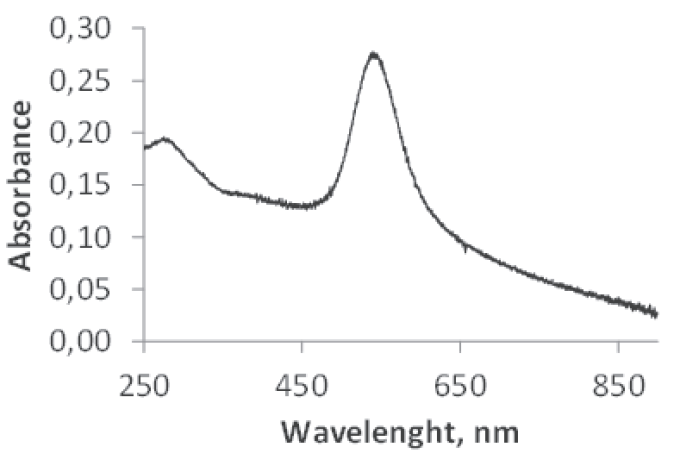

e)

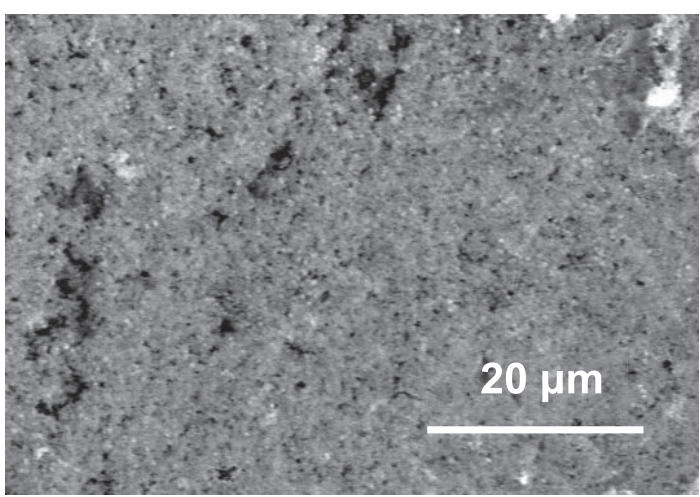

Fig. 1. Materials and methods: a) scheme of the flow-through electrochemical cell; b) method of standard addition of three patterns - image of the sample voltammetry curves of a) investigated sample, b) sample containing $1 \mathrm{ppb}$ of thallium added, c) sample containing $2 \mathrm{ppb}$ of thallium added, d) sample plus $3 \mathrm{ppb}$ of thallium added; c) exemplary diagram illustrating the method of determining the amount of thallium in the sample; d) UV-vis spectrum of lignosulfonate stabilized gold nanoparticles; and e) SEM image of working electrode surface 
The walnuts were removed from their outer husk and endocarp. Then the walnut shells were thoroughly washed with distilled water to remove all residues, and then were crushed in a ceramic mortar. The powdered shells were dried at $105^{\circ} \mathrm{C}$ to a constant weight. The thus-prepared walnut shells were stored in a closed dark container.

\section{Gold Colloid}

The study used lignosulfonate-stabilized gold nanostructures. The gold colloid was prepared from tetrachloroauric acid trihydrate and sodium ligninosulfonate DP 841 (Borregaard Lignotech) with a gold ion to biopolymer mass ratio of 3:7. The formation of nanostructured gold was confirmed by UV-vis spectrum showing a characteristic plasmon band as presented in Fig. 1d). The method of preparing lignosulfonate-stabilized gold colloid was described in our previous work [33].

\section{Sample Analysis Procedure}

The test solutions $(25 \mathrm{ml})$ were mixed with a set amount of the adsorbent and were placed on a shaker for a certain period of time. Next, the samples were taken from the flasks in order to determine the concentration of thallium ions remaining in the aqueous solution. The thallium concentration in the samples was determined by three standard additions. Fig. 1b) shows a series of voltammetric curves determined in aqueous solution without and with three toppings. Fig. 1c) illustrates a method of determining the concentration of thallium in the test sample. All samples were analyzed the same way by DPASV (accumulation time: $120 \mathrm{sec}$, accumulation potential $-900 \mathrm{mV})$. The results were evaluated on the basis of several additions of an internal standard (typically 3 additions). The detection limit of the method (calculated on a $3 \mathrm{SD}$ basis) was $50 \mathrm{pg} \mathrm{L}^{-1}$ $(0.25 \mathrm{pM})$ [32].

All measurements were carried out three times. Mean values of measurements are presented on graphs. Relative standard deviations (SD) are shown on the graphs as error bars. Depending on the sample tested, the SD value ranged from 0.7 to $2.1 \%$.

\section{Results and Discussion}

\section{Adsorption of Thallium on the Glass Surface}

In order to rule out the effect of the adsorption of thallium on the surface of laboratory glass, the impact of shaking time on the sorption of thallium in glass vials was examined. Tests were carried out with 1 ppm aqueous solution of thallium (I). Samples were analyzed after a time period of $0,15,35,100$, and 1440 minutes. The results of the test are shown in Fig. 2.

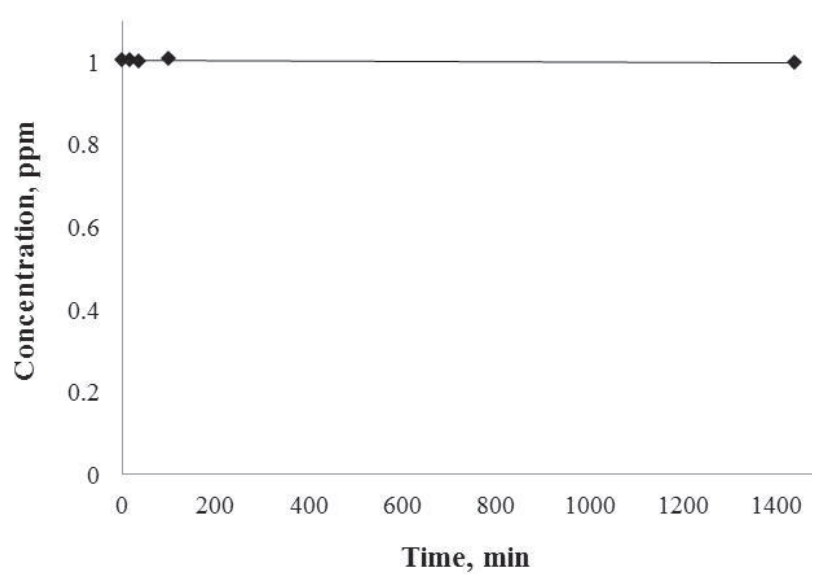

Fig. 2. Effect of shaking time on the concentration of thallium in the sample stored in a glass vial.

The graph clearly shows that shaking time did not affect thallium concentration, meaning that the adsorption of thallium ions on laboratory glass was negligible.

\section{Determining the Optimal Amount of Walnut Shell and Contact Time}

In order to determine the optimal amount of walnut shells needed to remove thallium ions from $25 \mathrm{ml}$ of 1 ppm thallium aqueous solution, four samples containing different amounts of biosorbents $(0.5,1.0$, 1.5 , and $2.0 \mathrm{~g}$ ) were analyzed. The flasks were placed in a shaker. The concentration of thallium for each sample was analyzed after a shaking time of $5,10,15,25,50$, 75, 90, and 110 minutes. Tests were performed without controlling the $\mathrm{pH}$, which varied from 3.25 to 3.31 and at ambient temperature (Fig. 3a).

From Fig. 3a) it can be concluded that the efficiency of removal of thallium from the aqueous solution is affected by the amount of the sorbent. The analysis results show that an increase in the efficiency of sorption is directly related to the amount of shells used in the sorption process. The most effective proved to be the use of walnut shell in the amount of $2 \mathrm{~g}$. For this amount of biosorbent, the sorption equilibrium was reached after 25 minutes.

\section{The Effect of Initial pH on Thallium Sorption}

It is well established that metal sorption on various sorbents is greatly influenced by $\mathrm{pH}$ and depends on the surface functional groups of the sorbent in terms of its dissociation and complexetion constants as well as metal ion chemistry in solution [34]. Therefore, we aimed to determine the optimal $\mathrm{pH}$ for the sorption of thallium on walnut shells. For this purpose, powdered shells in the amount of $2 \mathrm{~g}$ were placed in $25 \mathrm{ml}$ of aqueous solution of $1 \mathrm{ppm}$ thallium ions. The first sample was adjusted to $\mathrm{pH}=2.04$ and the sorption process was allowed to proceed. After $25 \mathrm{~min}$, the sample was removed from the shaker and the level of thallium in the solution was 
a)

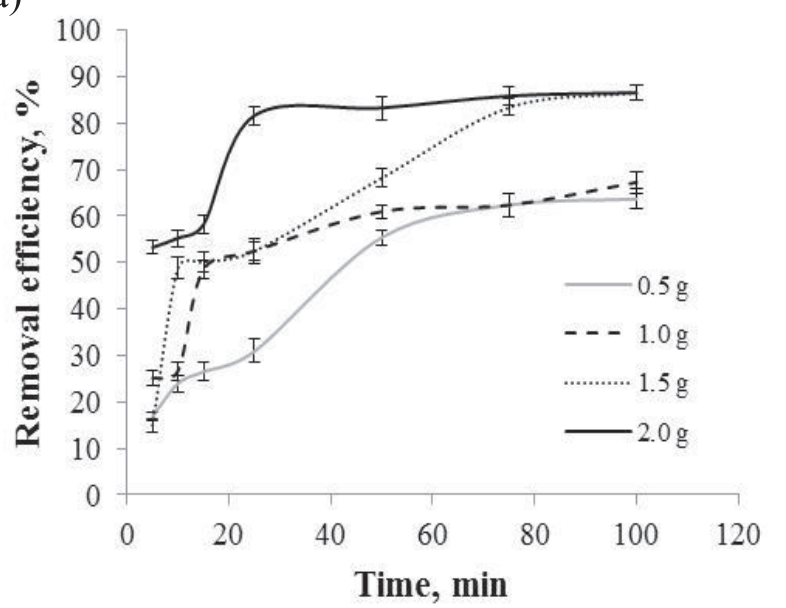

b)

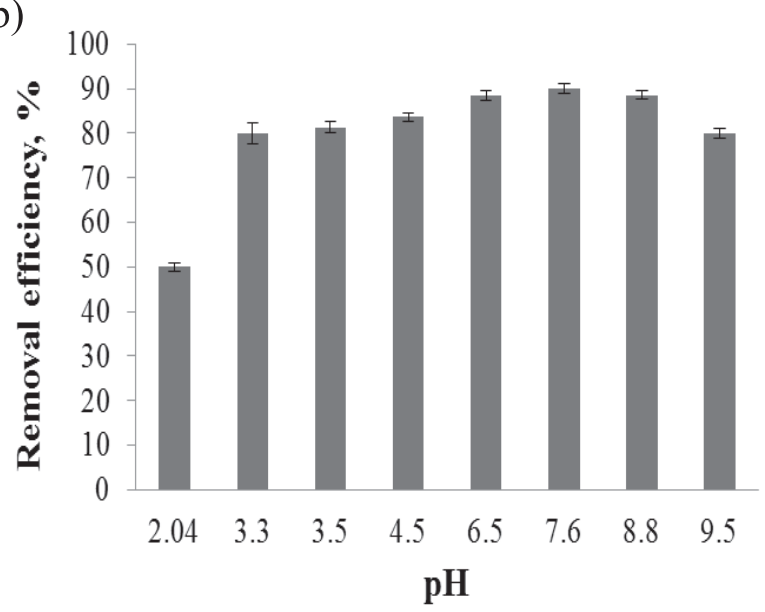

Fig. 3. Adsorption of thallium: a) Effect of contact time on removal of thallium by walnut shell for thallium concentration of $1 \mathrm{ppm}$ and adsorbent dosage of: (-) $0.5 \mathrm{~g},(--) 1.0 \mathrm{~g},(\cdots)$ $1.5 \mathrm{~g}$ and (-) $2.0 \mathrm{~g}, \mathrm{~b})$ Removal efficiency of thallium ions by walnut shell for different $\mathrm{pH}$ values.

determined by the same method. The result revealed that the adsorption was much less effective than in the case without $\mathrm{pH}$ adjustment. Further studies were carried out at seven different values of $\mathrm{pH}$ : 2.04, 3.3, 4.5, 6.5, 7.6, 8.8, and 9.5. The results obtained are shown in Fig. 3b).

As shown in Fig. 3b), the difference in the $\mathrm{pH}$ range of 4.5 to 7.5 is very small. For subsequent studies, we assumed that the optimal $\mathrm{pH}$ is in the range of 6.5 . Some reduction in the adsorption effectiveness above $\mathrm{pH} 7.5$ was observed. Moreover, after exceeding the $\mathrm{pH}$ of 8.8 , the desorption of thallium was observed (re-release of thallium ions from walnut shells). Sorption of thallium from the aqueous solution is much lower in the highly acidic environment and the increase in the basicity of the aqueous solution promotes the process of desorption $(\mathrm{pH}=8.8)$. Focusing on the obtained data, the process of adsorption of thallium for walnut shells is preferably carried out in a slightly alkaline or slightly acidic environment $(\mathrm{pH}=6.5 \div 7.5)$.
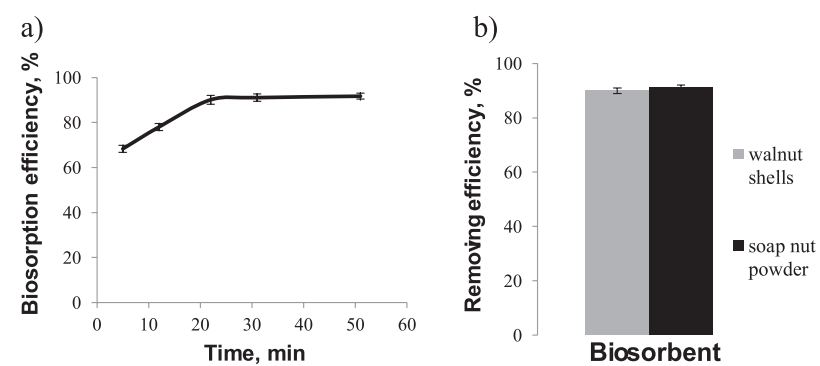

Fig. 4. a) Thallium sorption efficiency from an aqueous solution using soap nut powder, b) comparison of the efficiency of removal of the thallium by ( $\square)$ soap nuts powder and ( $\square$ ) walnut shells $(\mathrm{t}=30 \mathrm{~min}, \mathrm{pH}=7)$.

\section{Comparing the Sorption Properties of Walnut Shells and Soap Nut Powder}

Due to the expansion of the market for nuts used for washing or bathing, it was also interesting to investigate their sorption characteristics and to determine the capacity and the efficiency of sorption of commercial soap nut powder. $2 \mathrm{~g}$ of soap nuts were added to $25 \mathrm{ml}$ of aqueous solution containing $1 \mathrm{ppm}$ of thallium. The process was conducted at ambient temperature, the $\mathrm{pH}$ of the solution was brought to 7, and the mixture was shaken for 50 minutes. To study the adsorption kinetics, samples were also taken after 5, 10, 20, and 30 minutes. It was observed that during shaking the soap nuts showed remarkable foaming properties. This indicates that they contain compounds showing surfactant properties. This is one of the main differences between soap nuts and walnut shells, which did not show such properties.

From the results shown in Fig. 4a), it can be concluded that the efficiency of thallium sorption in the case of soap nuts is high and reaches $91.7 \%$. A time sufficient for effective adsorption using this sorbent was around 20 minutes. But even after 5 minutes, it was relatively high and reached $68.3 \%$. Due to the difference in the degree of fragmentation of both sorbents and hence the surface area, the comparison is not straightforward (Fig. 4b); the sorption efficiency is within the limit of measurement error (1\%).

\section{Effect of Thallium (I) Concentration on Biosorption Efficiency}

To determine the effect on the concentration of thallium on the adsorption process, various concentrations of thallium of $0.35 \mathrm{ppm}, 0.5 \mathrm{ppm}$, $1 \mathrm{ppm}, 1.5 \mathrm{ppm}$, and $2 \mathrm{ppm}$ were checked with the same amount of the adsorbent. The process was studied at the optimum $\mathrm{pH}$ of 6.5 and ambient temperature. The results are shown in Fig. 5.

The obtained results show the possibility of using walnut shells as biosorbent at the entire studied range of thallium concentrations from 0.35 to $2 \mathrm{ppm}$. As 


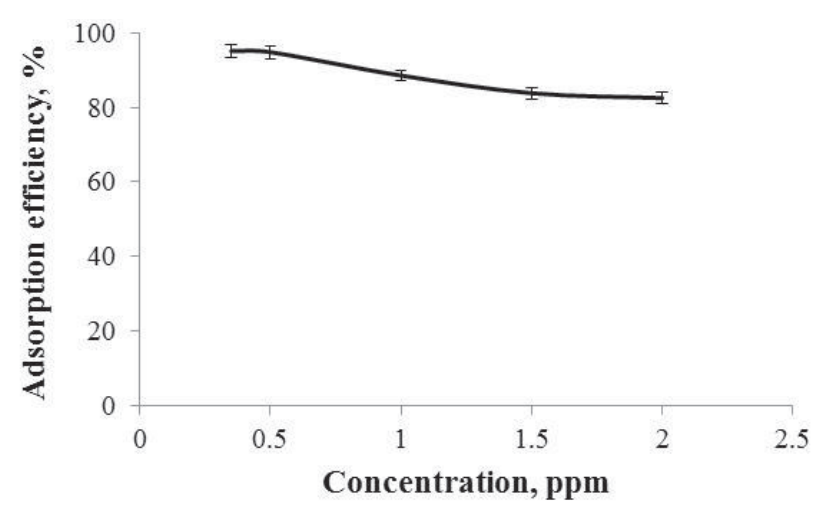

Fig. 5. Thallium concentration dependence of the efficiency of thallium sorption on walnuts in optimal conditions.

expected, the lower the concentration of thallium, the higher the efficiency of its adsorption with the set amount of the adsorber, e.g., for $0.35 \mathrm{ppm}$ thallium the sorption efficiency was $95.2 \%$. With a slight increase in the concentration of thallium to $0.5 \mathrm{ppm}$, the efficiency of adsorption decreased to $94.9 \%$, then to $88.6 \%$ for $1 \mathrm{ppm}$, and to $82.6 \%$ for $2 \mathrm{ppm}$. These results indicate good sorption properties of walnuts independent of the concentration of thallium.

\section{Biosorption Equilibrium}

Equilibrium data (the adsorption isotherms) describe the efficiency of the adsorption as a function of the concentration of the adsorbate. This part of the research was carried out using different concentrations of thallium (I) in the range 0.35 to $2 \mathrm{ppm}$.

Here, Langmuir and Freundlich adsorption equations were used to model the equilibrium between the adsorbed thallium on the walnut shell surface $\left(\mathrm{q}_{\mathrm{e}}, \mathrm{mg} / \mathrm{g}\right)$ and $\mathrm{Tl}^{+}$concentration in solution $\left(\mathrm{C}_{\mathrm{eq}}, \mathrm{mg} / \mathrm{l}\right)$ at a constant temperature. The Langmuir equation is the most common model used to quantify the monolayer sorption onto a surface with a finite number of equal adsorption sites at constant temperature and is presented in linear form by Eq. (1):

$$
\frac{C_{e q}}{q_{e}}=\frac{1}{q_{\max } b}+\frac{1}{q_{\max }} C_{e q}
$$

...where $\mathrm{q}_{\max }$ and $\mathrm{b}$ are Langmuir constants related to the maximum adsorption capacity and the energy of adsorption, respectively. $\mathrm{q}_{\max }$ and $\mathrm{b}$ can be determined from the linear plot of $\mathrm{C}_{\mathrm{eq}} / \mathrm{q}_{\mathrm{e}}$ versus $\mathrm{C}_{\mathrm{eq}}[35,36]$.
The empirical Freundlich equation based on the sorption on a heterogeneous surface is given in linear form by Eq. (2):

$$
\log q_{e}=\log K_{f}+\frac{1}{n} \log C_{e q}
$$

...where $\mathrm{K}_{\mathrm{f}}$ is Freundlich constant, an indicator of adsorption capacity, and $\mathrm{n}$ is Freundlich constant, an indicator of adsorption intensity.

Freundlich constants $\mathrm{K}_{\mathrm{f}}$ and $\mathrm{n}$ can be extracted from the intercept and the slope of the linearized plot. The Freundlich isotherm is more widely used, but provides no information on the monolayer adsorption capacity (in contrast to the Langmuir model) [35-38].

The two models were used to study the adsorption of thallium on walnut shells. The isotherms obtained were characterized by $\mathrm{R}^{2}=0.947$ and 0.991 for Langmuir and Freundlich models, respectively. The Adsorption parameters associated with the two models are presented in Table 1. It should also be noted that the value of the $\mathrm{n}$ parameter of the Freundlich equation is greater than 1, reflecting favorable adsorption [39].

\section{Effect of Colloidal Gold on Walnut Shell Sorption of Thallium}

The next stage of the research was to examine the possibility of improving the sorption capacity of walnut, which was over $90 \%$ in the optimal experimental conditions. To achieve this, colloidal gold was added. $165 \mu \mathrm{l}$ of gold colloid was added to $1 \mathrm{~g}$ of shelled walnuts, and supplemented with $12.5 \mathrm{ml}$ of solution with a concentration of $1 \mathrm{ppm}$ at $\mathrm{pH}=6.5$. The sample was shaken for 30 minutes. After this time, a sample was taken for analysis. The results compared with walnut shells are shown in Fig. 6a).

The drawing above illustrates that the colloidal gold additive affects the adsorption of thallium(I) ions from aqueous solution by walnut shells and improves sorption efficiency up to $99 \%$.

Literature data indicate that for other bioadsorbents for reactions conducted under optimal conditions, the degree of adsorption of thallium was up to $93 \%$ using solid waste of the oleum rosea process [40], $77.8 \%$ using Neosartorya fischeri strain [41], 96.5\% pistachio hull [42], and 98\% [43] and 99\% [44] using activated carbon as adsorbent. Walnut shells had also a good adsorption efficiency to remove $\mathrm{Pb}$ (II) and $\mathrm{Cd}(\mathrm{II})$ ions at $\mathrm{pH}=6(86.16 \%$ and $72.35 \%$, respectively $)$ [45].

Table 1. Adsorption equilibrium constants.

\begin{tabular}{|c|c|c|c|c|c|}
\hline \multicolumn{3}{|c|}{ Freundlich isotherm } & \multicolumn{3}{c|}{ Langmuir isotherm } \\
\hline $\begin{array}{c}\text { Adsorption capacity } \\
\mathrm{K}_{\mathrm{f}}(\mathrm{mg} / \mathrm{g})\end{array}$ & $\begin{array}{c}\text { Adsorption } \\
\text { intensity }(\mathrm{n}) \mathrm{g} / \mathrm{l}\end{array}$ & $\begin{array}{c}\text { Correlation } \\
\text { coefficient }\left(\mathrm{R}^{2}\right)\end{array}$ & $\begin{array}{c}\text { Adsorption capacity } \\
\left(\mathrm{q}_{\mathrm{e}}\right) \mathrm{mg} / \mathrm{g}\end{array}$ & $\begin{array}{c}\text { Adsorption equilibrium } \\
\text { constant }(\mathrm{b}) \mathrm{l} / \mathrm{mg}\end{array}$ & $\begin{array}{c}\text { Correlation } \\
\text { coefficient }\left(\mathrm{R}^{2}\right)\end{array}$ \\
\hline 1.329 & 2.021 & 0.991 & 0.985 & 9.853 & 0.947 \\
\hline
\end{tabular}


a)
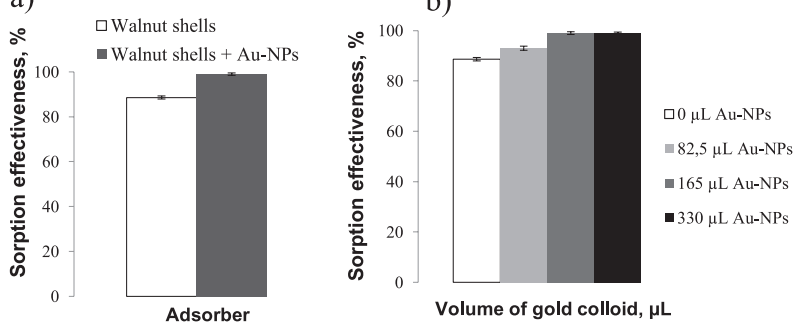

Fig. 6. Influence of nanogold for biosorption: a) comparison of the effectiveness of biosorption of walnut shells ( $\square$ ) and walnut shells plus modifier ( $\square)$, b) effect of colloidal gold addition on the effectiveness of sorption of walnut shell: () $0 \mu \mathrm{L},(\square) 82.5 \mu \mathrm{L},(\square) 165 \mu \mathrm{L}$ and $(\bullet) 330 \mu \mathrm{L}$.

The addition of colloidal gold improved sorption by $10.4 \%$. The next study was to determine the optimal amount of the supplement. For this purpose, the dose of colloidal gold stabilized by lignosulphonate was reduced by about half $(82.5 \mathrm{uL})$ and doubled $(330 \mu \mathrm{L})$, which would determine which direction to follow when selecting amounts. The number of walnut shells was $1 \mathrm{~g}$ and the adsorption process was carried out under optimal conditions $(25 \mathrm{ml}$ of aqueous solution with a thallium concentration of $1 \mathrm{ppm}$, ambient temperature, $\mathrm{pH}=7$ and agitation time of $30 \mathrm{~min}$ ). The results are presented in Fig. 6b). Reduction of the dose by half contributed to reducing sorption efficiency by $6 \%$ (from $99 \%$ to $93 \%$ ). However, doubling the amount did not cause any significant changes and the difference was $0.1 \%$ (from $99 \%$ to 98.9 ), which is assumed to be no change.

\section{Conclusions}

We found that differential pulse anodic stripping voltammetry is suitable for studying the adsorption of thallium on nuts due to its high sensitivity and selectivity. The obtained results show that chopped shells of walnuts and soap nuts are effective sorbents for thallium (I) ions with the removal efficiency over $90 \%$. The sorption was most effective at $\mathrm{pH}=7.5$ and the adsorption equilibrium was achieved after ca. $30 \mathrm{~min}$. The addition of colloidal gold improves the sorption ability of the walnut shells to over $99 \%$. The walnut shells seem to be a cheap and renewable sorbent that can be used for cleaning traces of heavy metals from water.

\section{Acknowledgements}

This work was performed with the financial support of the Polish Ministry of Science and Higher Education (research project 03/31/DSPB/0357). The authors are grateful to L. Lawniczak for assistance preparing the manuscript.

\section{Conflict of Interest}

The authors declare no conflict of interest.

\section{References}

1. MAHVI A.H., NOURI J., OMRANI G.A., GOLAMI F., Application of Platanus orientalis leaves in removal of cadmium from aqueous solution, World Appl. Sci. J., 2 (1), 40, 2007.

2. GROESSLOVA Z., VANEK A., MIHALJEVIČ M., ETTLER V., HOJDOVÁ M., ZÁDOROVÁ T., PAVLÜ L., PENÍŽEK V., VANĚČKOVÁ B., KOMÁREK M., CHRASTNÝ V., ASH C. Bioaccumulation of thallium in a neutral soil as affected by solid-phase association, J. Geochem. Explor., 159, 208, 2015.

3. RICKWOOD C.J., KING M., HUNTSMAN-MAPILA P. Assessing the fate and toxicity of thallium I and thallium III to three aquatic organisms, Ecotoxicol. Environ. Saf., 115, 300, 2015.

4. WOJTKOWIAK T., KARBOWSKA B., ZEMBRZUSKI W., SIEPAK M., LUKASZEWSKI Z. Miocene colored waters: A new significant source of thallium in the environment, J. Geochem. Explor., 161, 42, 2016.

5. YU-TAI T., HUANG C., KUO H., WANG H., SHEN W., SHIH T., CHU N. Central nervous system effects in acute thallium poisoning, Neurotoxicology, 27, 291, 2006.

6. DMOWSKI K., KOZAKIEWICZ A. Bioindicational search for thallium in the areas of southern Poland, Kosmos, 51 (2), 151, 2002.

7. KABATA-PENDIAS A., PENDIAS H. Biogeochemistry of trace elements, Warszawa, PWN, 1999.

8. MAŁUSZYŃSKI M. Thallium in Environment, Ochrona Środowiska i Zasobów Naturalnych, 40, 31, 2009.

9. PAULO A., LIS J., PASIECZNA A. Thallium at the end of the twentieth century, Przegląd Geologiczny, Warszawa, 5, 403, 2002.

10. RALF L., TWISS M.R. Comparative toxicity of thallium(I), thallium(III), and cadmium(II) to the unicellular alga Chlorella isolated from Lake Erie, Bull. Environ. Contam. Toxicol. 68 (2), 261, 2002.

11. VANĚK A., CHRASTNÝ V., MIHALJEVIČ M., DRAHOTA P., GRYGAR T., KOMÁREK M. Lithogenic thallium behavior in soils with different land use, J. Geochem. Explor., 102 (1), 7, 2009.

12. KRASNODĘBSKA-OSTRĘGA B., KACZOROWSKA M., GOLIMOWSKI J. Ultrasound-assisted extraction for evaluation of element mobility in bottom sediment collected at mining and smelting $\mathrm{Pb}-\mathrm{Zn}$ ores area $\mathrm{In}$ Poland, Microchim. Acta, 154, 39, 2006.

13. MARQUÉS M.J., MARTÍNEZ-CONDE E., ROVIRA J.V., ORDÓÑEZ S. Heavy metals pollution of aquatic ecosystems in the vicinity of a recently closed underground lead-zinc mine (Basque Country, Spain), Environ. Geol., 40 (9), 1125, 2001.

14. XIAO T., GUHA J., BOYLE D., LIU C.Q., CHEN J. Environmental concerns related to high thallium levels in soils and thallium uptake by plants in southwest Guizhou, China, Sci. Total Environ., 318, 223, 2004.

15. ZHANG G.P., LIU C.Q., YANG Y.G., WU P. The characteristics of heavy metals and sulfur isotope of water draining lead-zinc mine in carbonate area, Water, Air, Soil Pollut., 155, 51, 2004. 
16. GUR N., TOPDEMIR A. Effects of some heavy metals on in vitro pollen germination and tube growth of apricot (American vulgaris lam.) and cherry (Cerasus avium 1.), World Appl. Sci. J., 4 (2), 195, 2008.

17. MAHVI A.H., BAZRAFSHAN E. Removal of cadmium from industrial effluents by electro coagulation process using aluminum electrodes, World Appl. Sci., J., 2 (1), 34, 2007.

18. NANDI B., GOSWAMI A., PURKAIT M. Removal of Cationic Dyes from Aqueous Solutions by Kaolin: kinetic and equilibrium studies, Appl. Clay. Sci., 42 (3-4), 583, 2009.

19. YAGUB M.T., SEN T.K., AFROZE S., ANG H.M. Dye and its removal from aqueous solution by adsorption: A review, Adv. Colloid Interface Sci., 209, 172, 2014.

20. BIRUNGI Z., CHIRWA E. Interpretation of uptake kinetic of thallium and cadmium on surfaces of immobilized green algae as biosorbents, Chem. Eng. Transactions, 49, 421, 2016.

21. ESCUDERO L.B., GARCÍA C.B., DA SILVA S.M., BARÓN J.H. An eco-friendly cellular phase microextraction technique based on the use of green microalgal cells for trace thallium species determination in natural water samples, Anal. Methods, 7, 7480, 2015.

22. SUN J., ZOU X., XIAO T., JIA Y., NING Z., SUN M., LIU Y., JIANG T. Biosorption and bioaccumulation of thallium by thallium-tolerant fungal isolates, Environ. Sci. Pollut. Res. 22, 16742, 2015.

23. HE Y., MEN B., YANG X., WANG D. Bioturbation/ bioirrigation effect on thallium released from reservoir sediment by different organism types, Sci. Total Environ., 532, 617, 2015.

24. JUANG R.S., WU F.CH., TSENG R.L. Mechanism of adsorption of dyes and phenols from water using activated carbons prepared from plum kernels, J. Colloid. Interface. Sci., 227, 437, 2000.

25. DADOSH T. Synthesis of uniform silver nanoparticles with a controllable size, Mater. Lett., 63, 2236, 2009.

26. GUO S., WANG E. Synthesis and elektrochemical applications of gold nanoparticles, Anal. Chim. Acta., 598, 181, 2007.

27. BEQA L., SINGH A.K., KHAN S.A., SENAPATI D., ARUMUGAM S.R., RAY P.C. Gold nanoparticle-based simple colorimetric and ultrasensitive dynamic light scattering assay for the selective detection of $\mathrm{Pb}$ (II) from paints, plastics, and water samales, ACS Appl. Mater. Interfaces., 3 (3), 668, 2011.

28. CHAUHAN N., GUPTA S., SINGH N., SINGH S., ISLAM S.S., SOOD K.N., PASRICHA R. Aligned nanogold assisted one step sensing and removal of heavy metal ions, J. Colloid. Interface Sci., 363, 42, 2011.

29. HUA C., ZHANG W.H., DE ALMEIDA S.R.M., CIAMPI S., GLORIA D., LIU G., HARPER J.B., GOODING J.J. A novel route to copper(II) detection using 'click' chemistry-induced aggregation of gold nanoparticles, Analyst., 137, 82, 2012.

30. KIM Y., JOHNSON R.C., HUPP J.T. Gold NanoparticleBased Sensing of "Spectroscopically Silent" Heavy Metal Ions, Nano Lett., 1 (4), 165, 2001.
31. ZHIYANG Z., JUN Z., TINGTING L., DAWEI P., LINGXIN CH., CHENGLI Q., ZHAOPENG C.H. Labelfree colorimetric sensing of cobalt(II) based on inducing aggregation of thiosulfate stabilized gold nanoparticles in the presence of ethylenediamine, Mater. Lett., 63, 2236, 2009.

32. KARBOWSKA B. Presence of thallium in the environment: sources of contaminations, distribution and monitoring methods, Environ Monit Assess, 188, 640, 2016.

33. KONOWA E., MODRZEJEWSKA-SIKORSKA A., MILCZAREK G. Synthesis and multifunctional properties of lignosulfonate-stabilized gold nanoparticles, Mater. Lett., 159, 451, 2015.

34. PINO G.H., SOUZA DE MESQUITA L.M., TOREM M.L., SAAVEDRA PINTO G.A. Biosorption of cadmium by green coconut shell powder, Miner. Eng. 19, 380, 2006.

35. ERDEN E., KAYMAZ Y., PAZARLIOGLU N.K. Biosorption kinetics of a direct azo dye Sirius Blue K-CFN by Trametes versicolor, Electron. J. Biotechnol., 14 (2), 1, 2011.

36. MORADI O., NOROUZI M., FAKHRI A., NADDAFI K. Interaction of removal Ethidium Bromide with Carbon Nanotube: Equilibrium and Isotherm studies, J. Environ. Health. Sci., 12, 17, 2014.

37. JAYARAM K., MURTHY I.Y.L.N., LALHRUAITLUANGA H., PRASAD M.N.V. Biosorption of lead from aqueous solution by seed powder of Strychnos potatorum L, Colloids Surf. B Biointerfaces., 71, 248, 2009.

38. MARTÍN-LARA M.A., BLÁZQUEZ G., RONDA A., PÉREZ A., CALERO M. Development and Characterization of Biosorbents To Remove Heavy Metals from Aqueous Solutions by Chemical Treatment of Olive Stone, Ind. Eng. Chem. Res., 52 (31), 10809, 2013.

39. KUMAR Y. P., KING P., PRASAD V. Removal of copper from aqueous solution Rusing Ulva fasciata sp. - A marine green algae, J. Hazard. Mater., 137, 367, 2006.

40. YAPICI S., EROGLU H. Batch biosorption of radioactive thallium on solid waste of oleum rosea process, J. Chem. Technol. Biotechnol., 88 (11), 2082, 2013.

41. URÍK M., KRAMAROVÁ Z., ŠEVC J., ČERŇANSKÝ S., KALIŠ M., MEDVEĎ J., LITTERA P., KOLENČÍK M., GARDOSOVA K. Biosorption and Bioaccumulation of Thallium(I) and Its Effect on Growth of Neosartorya fischeri Strain, Pol. J. Environ. Stud., 19 (2), 457, 2010.

42. SHEIBANI A., ZARE-KHORMIZI M. Application of factorial design for adsorption of thallium(III) ion from aqueous solutions by pistachio hull, Indian J. Chem. Techn., 19, 48, 2012.

43. HANAFI A. Adsorption of cesium, thallium, strontium and cobalt radionuclides using activated carbon, J. At. Mol. Sci., 1 (4), 292, 2010.

44. TWIDWELL L.G., WILLIAMS C. Potential Technologies for Removing Thallium from Mine and Process Wastewater: An Abbreviated Annotation of the Literature, Eur. J. Miner. Process. Environ. Prot., 2 (1), 1, 2002.

45. KAMAR F., NECHIFOR F., MOHAMMED A.C., CRACIUN M.E. Removal of Lead and Cadmium Ions from Aqueous Solution using Walnut Shells as Low-Cost Adsorbent Materials, Rev. Chim., 66 (5), 615, 2015. 